\title{
wellcometrust \\ Chapter 11. Watchful Waiting: Temporalities of crisis and care in the UK National Health Service
}

\author{
Professor Lisa Baraitser ${ }^{1}$ and Dr William Brook ${ }^{2}$
}

\section{Abstract}

This paper opens up the relationship between vulnerability and the temporalities of care. It takes 'care' as not just a material practice that supports, manages and sustains vulnerable bodies, but as a temporal practice, one that produces time in situations that are otherwise felt to be stuck or 'chronic'. It draws on some co-written anecdotes about the use of 'watchful waiting' by medical practitioners working in general practice in the UK's National Health System (NHS) to think through the meanings of waiting in relation to chronic health and mental health crises. The offer of 'watchful waiting' as a response to 'chronic crisis' becomes a test case for understanding a more general condition of watchful waiting as a form of care, in a context in which waiting for healthcare has become an agony for many, experienced as a form of abandonment or a key sign of health service failure. The paper attempts to re-think 'waiting times' within a wider history of the temporalities of care, in order to elucidate the ways an offer of waiting can itself be understood as a response to vulnerability through a practice of staying with or alongside the chronic temporalities of others.

Keywords: Temporality, waiting, care, crisis, mental health, general practice, NHS

\section{Introduction}

In 'Contradictions of Capital and Care' Nancy Fraser attempts to get hold of the 'crisis in care' that she identifies as a major contemporary public discourse within developed nations in the global north (Fraser, 2016). Care, in her terms, is a set of social capacities, those that are necessary for birthing and raising children, for sustaining and maintaining kinship groups and community connections more broadly, as well as the specific practices of attending to the needs of those who are unwell, or need support for disabilities, age and frailty, or are at the end of life (1). The practices she outlines imply a willingness to hold together relational connections that are

Author Affiliations: 1 Department of Psychosocial Studies, Birkbeck, University of London. 2 General Practitioner (NHS), London.

This is a draft of a book chapter that has been accepted for publication by Oxford University Press as Baraitser, L., and Brook, W., (2021) Watchful Waiting: Temporalities of Crisis and Care in the UK National Health Service, in the forthcoming book Vulnerability and the Politics of Care: Transdisciplinary Dialogues, Eds., Victoria Browne, Jason Danely, and Doethe Rosenow, Proceedings of the British Academy, Oxford University Press, Oxford, due for publication on the $28^{\text {th }}$ February 2021. 
Vulnerability and the Politics of Care: Transdisciplinary Dialogues

constantly under strain, a form of labour that is ongoing, as the connections break and are reformed as the very condition of relationality. The forms of care she describes are often subsumed under the term 'social reproduction' - the affective, material and largely unpaid labour that has been traditionally assigned to women, or to men 'feminized' through this labour, which also ramifies along the interlocking axes of class, 'race', and global patterns of migration that are one of the afterlives of colonisation (Williams, 2010). The powerless tend to care for the powerful, and not the other way around. Equating care with social reproduction, Fraser claims that the current crisis of care is 'best interpreted as a more or less acute expression of the social-reproduction contradictions of financialized capitalism' (1). Capitalism, in other words, is animated by an inherent contradiction or 'crisis tendency' that manifests in the present strains on care in the global north that have deep roots in the structure of the social order (1). On the one hand, social reproduction is a condition of possibility for sustained capital accumulation, given that capitalism feeds on the reproduction of the next generation of consumers and workers, as well as the material conditions that allow capital to extract profit from living labour. On the other hand, capitalism's orientation to unlimited accumulation constantly destabilizes the very process of social reproduction on which its future is guaranteed, given that care practices are time consuming, can be deemed 'useless' and labour intensive, and run contra to the relentless drive towards productivity. In each successive version of capitalism (liberal, state managed, financialized global or neoliberal), Fraser argues, this crisis tendency is expressed in a different way, but it is never eradicated. From this perspective, care, crisis and capital cannot get free of one another. Capitalism cannot do without care, any more than it can function outside of the temporality of crisis. And although Fraser places social reproduction as external to capital accumulation, care does not sit outside the historical manifestations of capitalism, but is bound into its seams, and therefore vulnerable to the logic of both permanent crisis, and capitalism without end.

The UK publicly funded healthcare system is narrativized collectively, and now with increased urgency, as being 'in crisis. This discourse came into particular focus in 2018, as the National Health Service (NHS) turned 70, and its birthday occasioned a national debate about the 'health' of the health service and whether it is now in 'permanent crisis.' ${ }^{1}$ Much of the analysis has centred on a combination of complex problems. These include an overall slowdown of government spending on healthcare; an aging population with complex needs; and a collapse in social care at local levels due to 'austerity' policies over the last decade being passed down to local councils. In addition, there is evidence of an increase of chronic health and mental health conditions for those most affected by widening inequalities and increasing poverty rates which puts pressure on all aspects of the health service. James Meek (2018) has elaborated two narratives that appear to describe two separate realities currently coexisting within the NHS. The first is the reality of yet another round of health service restructuring, with the aim that most healthcare will take place at or close to home, reserving hospitals for trauma, intensive care and research. Here, restructuring in the present is a response to current crisis and is invested with the hope that it can bring about the change required to secure the health services' long term future. The other reality is that the NHS is simply in an ever deepening, ongoing and enduring crisis due to chronic underfunding, creeping privatization, and a withdrawal from Europe that will lead to further staff shortages, demoralization and burnout. In one narrative it appears that 'crisis' is precisely what may bring about change, an upturn in the fate of the nation's health service and the preservation of its attachment to the ideal of the welfare state. In the other, crisis cannot bring about change. It sets in as a permanent elongated 'chronic' condition, one that comes to

\footnotetext{
1 See for example, newspaper articles in The Independent, The Daily Mail and the Guardian in the early months of 2018: https://www.independent.co.uk/news/health/nhs-70-seventy-national-health-service-video-crisis-a8432346.html, https:// www.dailymail.co.uk/health/article-6491697/NHS-crisis-worse-years-worst-winter.html, https://www.theguardian.com/ healthcare-network/2018/jan/04/nhs-under-threat-new-model-of-care.
}

1 For a more in depth analysis of the crisis in the NHS see Meek, J., (2018), and The Kings Fund (https:// www.kingsfund.org.uk/projects/nhs-in-crisis). For further resources on the future of publically funded health and social care in the UK, see Appleby, J., (2013); Bottery, S, et al., (2018); Charlesworth A, et al., (2017), Emmerson, C \& Pope, J, (2018), Ham, C, (2019), Ham, C. et al, (2018) National Audit Office, (2016); Roberts, et al., (2012) and Thorlby R, et al., (2018). 
define the temporality of healthcare itself. Even occupying these two realities simultaneously requires a certain form of affective and temporal labour whereby a petrified present in permanent crisis, and an optimistic unfolding future, have to be somehow brought into relation with one another. Meek (2018) points out the almost farcical paradox of the new acronym for the solution to holding these two discourses together - the STP. ${ }^{2}$ S for Sustainability, T for Transformation, P for either Plan, or Partnership, no-one seems quite sure. Either way, Meek points out, sustainability and transformation pull in opposite directions. If the NHS has to all extents and purposes run out of money, then transformation is an impossibility, a madness even.

In this chapter, we aim to think about how care, crisis and vulnerability play out in a 'close to home' setting - the local General Practice surgery in England ${ }^{3}$ - in relation to wider cultural narratives about crisis in the NHS. These are situated within broader narratives about time itself being 'in crisis' as we will elaborate below. If care is somehow 'slow', 'unproductive', monotonous, and time consuming, and if current conditions are those of a petrified present in which time itself has seized up and can no longer flow, what new forms of vulnerability are produced by this temporal paradox? What do they look and feel like, and how might we respond, with decreasing resources and especially a decreasing sense of there being 'enough time', whether at an individual or a planetary level? What is care in relation to the temporality of 'permanent crisis'?

Our way to try to work on these questions is through the temporal trope of 'waiting'. We want to understand 'waiting' as a form of care, even under conditions of individual and institutional crisis. Waiting, in fact, has always been a major marker of the quality of the NHS, 'timely' healthcare being seen as integral to care's quality. Indeed, waiting times have been used in debates about the role of the state in providing a layer of basic care for all citizens since the inception of the health service in 1948. Who should wait and for how long are questions that turned waiting for healthcare into a political football in the post-war period. The hospital bed crisis in the 1950s, for instance, led to the political decision to reduce long-stay hospital inhabitants - a step that had significant implications for care of the poor and elderly, those with mental health conditions, for categorisations of chronic illness and disability, and the role and structure of primary care itself (Bridgen, 2001; Denham, 2006; O'Hara, 2007; Perry, 2000, Timmins, 1996; Williamson, 2015). The aggressive privatization that was instigated in the 1980s under the Thatcher government was driven in part by the development of management devices that could measure waiting, in the form of both waiting lists and waiting times. These were used to prop up arguments that a healthcare service that entailed a reasonable wait to see a specialist doctor could not be fully funded through tax, and more 'choices' should be available for those who wanted and were able to pay. Though a publicly funded system was in the end retained, it was only secured on the basis that it would allow the introduction of new managerial methods and non-medical managers into the system (Klein, 2006; Rivett, 1998; Timmins, 1996). Disastrously, both Blair governments proved how implementing methods of managerial performance and formal performance targets were more perniciously effective than direct privatisation, with waiting times being the explicit mechanism used to single out hospital managers as poor performers during the 'Targets and Terror' system that the Labour government rolled out in the 2000s (Bevan and Hood, 2006; Propper et al. 2008).

Yet waiting is central to healthcare, and care more widely. Though waiting can feel intolerable - the anxious wait for diagnosis, waiting whilst in bodily and mental pain, the waiting bound up in treatment, in chronic conditions, in the infuriating bureaucracy of healthcare - and at times is simply dangerous, it also sits at the core of the practice or offer of care. Even to use the word 'patient' is to recognise, at least at an etymological level, the endurance, suffering, and resilience of those in need of healthcare, and those who provide it, as they both wait and see what giving time to a situation brings. Extended temporalities condition all experiences of health, wellbeing, illness, treatment, recovery, chronicity, birth and dying. Whilst waiting can be a synonym for things

2 See https://www.england.nhs.uk/integratedcare/stps/view-stps/

3 In the UK context, the general practice surgery is the local medical centre or clinic that is free and open to all residents, and usually the first point of access into wider medical services. 
going wrong, it is also a practice of careful attention. Indeed, care, as we understand it, is a temporal practice; not just a relational practice that develops over time, or one that takes time, but a practice that produces time in conditions that are otherwise felt to be stuck and unable to change.

In her discussion of what she calls 'care time', Maria Puig de la Bellacasa elaborates how care both takes time and involves 'making time of an unexceptional particular kind' (Puig 2017: 206). This is time in which nothing much appears to happen other than the ordinary maintenance work that enables the sustenance of livable and lively worlds (206). Although affectively care time can be enjoyable, she writes, it is also 'very tiresome, involving a lot of hovering and adjusting to the temporal exigencies of the cared for' (206). This precise yet unexceptional practice of 'hovering and adjusting' is, we would argue, the often neglected, poorly paid and yet morally pressurised work that is practiced across the health service every moment of every day, especially by nurses, porters, cleaning staff, receptionists, administrators, ambulance drivers, and numerous other support workers and health practitioners, as well as doctors. Care time, Puig de la Bellacasa states, 'suspends the future and distends the present' (207), producing the time for careful attention by pushing back on affective engagements with hopeful projections into the future, the pleasures of the present, or the accumulated joys and regrets of the past. One of the forms of everyday care, then, is that of waiting, requiring a certain suspension of the temporal affectivities of emergency, fear and anxiety, in order to allow for the 'hovering and adjusting' that makes up caring attention. ${ }^{4}$

\section{Waiting 'Now'}

What, however, does it mean to be asked to wait now, even if it is offered as a form of care? And what is the 'now' in this question? It is clear that different historical epochs have different temporal preoccupations: Walter Benjamin in the early years of the $20^{\text {th }}$ century asserted that the new temporal horizon of modernity was characterized by distraction, shock, and a sense of temporal crisis (Benjamin, 1999); Paul Virilio described the decades after WWII as a culture of speed he names 'dromology' that operates according to the logic of acceleration (Virilio, 1986); and others have extended this analysis to include the acceleration not just of social life but of social change itself. ${ }^{5}$ One vital critique of time in the $20^{\text {th }}$ century has revealed how these characterisations of temporal crisis rely on a European model of time imposed by the West on 'the rest' through colonization and the temporal structures of Empire, that come to mediate forms of relating to, and representing, the world (Vázquez 2009, Chakrabarty, 2009, Nanni 2012). Time is not the backdrop to social life, but produces the political and social realities in which we live.

Despite the focus on speed, however, there is a significant body of work emerging in social theory that argues that the first decades of the twenty-first century attest not just to speeded up time, but to the contradictions of experiences of the rapid acceleration, on the one hand, and the simultaneous 'slow violences', as Rob Nixon puts it, of contemporary capitalism on the other (Nixon, 2011). The acceleration of communications technologies, or the acceleration of social change, for instance, plays out alongside the 'deep time' violence produced by the delayed effects of nuclear and plastic waste. Slow violences may affect whole populations - we can think of the chronic effects of permanent debt and austerity policies that destroy hopes for a better life in the future (Berlant, 2011, Baraitser, 2017). Slow violence and rapid acceleration work in tandem, in ways that not only 'wear out' particular bodies and minds, but produce new and brutal forms of exclusion from public institutions such as the health service, whose very purpose is to sustain life projects. This results in the now chronic deterioration of the mental and physical health of particular embodied subjects.

4 See Baraitser 2017 for a more extended discussion of the relation between care and the elongated temporalities of staying, maintaining, repeating, delaying, enduring, recalling, and remaining.

5 See Crary, 2013; Duffy, 2009; Luhmann 1976; Nowotny, 1994; Rosa 2003, 2013; Rosa \& Scheurman 2009; Southwood, 2011; Virilio 1986, 2010, Wajcman, 2014. 
Yet instead of a call to action, these conditions appear to induce a permanent condition of waiting. The Invisible Committee $^{6}$ suggests that in conditions of 'crisis capitalism' we are all kept in a 'chronic state of near-collapse '(2009: 31) so that the future, far from unfolding, or opening onto a better life, brings about simply more of the same. It appears, as Amy Elias has argued, that 'humankind has created its own version of durational time inside (rather than outside) the box of historicity' (Elias 2016: 36), producing a form of 'incarceration' in the present that she terms 'techno-duration'. In other words, it is precisely the temporality raised by the question of waiting in an elongated and apparently frozen present that may come to describe time consciousness in the twenty-first century. This caesura, after all, has duration. We differentially live it, are living in it, enduring it. Permanent crisis, we would argue, produces new forms of vulnerability.

\section{Chronic Crisis}

In 'The Stakes of Crisis' Janet Roitman asks:

'How did crisis, once a signifier for a critical, decisive moment, come to be construed as a protracted historical and experiential condition? The very idea of crisis as a condition suggests an ongoing state of affairs. But can one speak of a state of enduring crisis? Is this not an oxymoron?' (Roitman 2016: 18)

Crisis appears to bind together the temporalities of both urgency (the critical decisive moment) and chronicity (a protracted enduring condition). It derives from 'Krino', Roitman explains, the Ancient Greek term that indicates a process of separation, decision, choice or judgement. In the Hippocratic school, as part of medical grammar, it originally denoted the turning point in a disease, where life and death hung in the balance. It was a point that therefore called for a decision to be made, a judgement between alternative paths both of the disease and its treatment. In many ways it still retains this meaning in contemporary medical grammar. A crisis is still seen as a turning point in an illness, one that entails judgement, even if the decision is to do what appears to be nothing: to monitor, to hold one's nerve, to watch and wait.

Roitman, however, engages at length with the work of the late German historian Reinhardt Koselleck and his conceptual history of crisis ${ }^{7}$ to show how crisis shifts from this early Greek meaning of judgement, to 'a protracted historical and experiential condition' by the end of the $18^{\text {th }}$ century. It is only in this period that European societies begin to understand history as a kind of agent, a force that joins together individual accounts of events, and events of the past (Szerszynski, 2017). Through a process in which the Greek meaning of krino gets conjoined in Christian theology to the notion of judicium - judgement before God - crisis eventually comes to entail prognosis, a prognosis of time (or history) itself (Roitman 2016: 20). Historical consciousness, that is, specifically means that time is no longer a medium in which histories take place, but history is itself a temporality on which one can make a judgement, and therefore on which one can act. History consolidates itself as force through the new capacity for judging time in terms of its significance. Roitman describes crisis, then, as an 'enabling blind spot' - it has no content, per se, but is necessary for the production of historical knowledge as it brings with it an awareness of our own historicization $(2016,19)$. Newness, or new historical times, are inaugurated through a diagnosis, or judgement, that the social fabric is in need of some form of repair, and that the future is open and contingent on action in the present that can bring about a different future from the one predicted by the problems of the past. Our very capacity to think of history as something that we can intervene in, that we can fix in the name of a different future, is a fundamentally modern perspective that is sutured through the concept of crisis.

6 The Invisible Committee is the nom de plume of an author or group of authors of the works The Coming Insurrection (2009); To our Friends (2015); and Now (2017). 
What this implies, Roitman argues, is that in modern times, as we move away from the idea of historical time approaching the Last Judgement, and move towards a world-immanent history, the more we feel in crisis. Neuzeit is narrated as crisis after crisis, or in permanent crisis, because of the constant, allegedly accelerating production of both this open future and the utopian hope of its fulfilment (Roitman 2014: 17). The way crisis operates in modern consciousness is to suggest that the particular crisis one is currently in - Roitman's own example is the global financial crash of 2008, but we could look at the crisis of the NHS, the crisis of social care that we began with, or even climate crisis - could be the last singular crisis that a society faces, after which history will look entirely different in the future. However, in Neuzeit we can only actually lurch from crisis to crisis as the very condition of the contemporary.

Similarly, if we turn to the sphere of healthcare, one way to understand the predicament of contemporary medicine is that it is caught in a new politics, one that Eric Cazdyn calls 'the new chronic' (Cazdyn, 2012). Medicine does not operate in a realm that is separate from politics and culture, but comes together with political and cultural discourses to manage rather than cure disease, paralleling global capitalism's aims for a continual state of crisis management that perpetuates the inequalities of the now (Cazdyn, 2012). Cure, after all, is not just a term that implies the alleviation of illness, but the alleviation of social ills that we still believe that we can fix in the now, on behalf of future generations. Cazdyn suggests that if we want to understand a system and make some form of significant change beyond symptom management, we have to look away from what appears to be the immediate crisis and towards the permanent crisis that is at work even when the system is functioning well. This crisis, he writes, constitutes the system itself; the system cannot function without its internal crisis or contradictions, echoing Fraser's reading of capitalism. Crisis is what happens when the system is working, it is 'always already with us, if it is the rule of the system rather than the exception' (Cazdyn, 2012: 3). Where Fraser may argue that the contradictions of capitalism are the very point that a particular phase of capitalist society may eventually give way or mutate, for Cazdyn we must embrace the 'already dead', the ongoing state of a decision needing to be made, rather than looking for the particular point of leverage that appears in historical time in the form of the contradiction.

What we want to draw out here, however, through this engagement with Roitman, is her crucial claim that crisis narratives themselves cannot produce alternative narratives or histories. Because judgement (i.e. critique) and crisis cannot disentangle themselves from one another, critique cannot propose an alternative narrative without crisis. This is its internal and structural limit. Crisis is the way in which we may critique both capitalism and imperialism, for instance, but crisis narratives themselves do not produce a different future. How, then, can we narrate a future without crisis, Roitman asks? 'How can we imagine that which fundamentally excludes our judgement, that which calls for no decision?' (Roitman 2014: 90, emphases added). This seems to us a vital question for understanding the production of new vulnerabilities in relation to permanent crisis, and what might constitute a response. Crisis, as it unfolds at the levels of the personal, the institutional, and the temporal, may call less for judgement, and rather, paradoxically, call for the suspension of judgement. Here the offer would be a form of care that calls for no decision, that appears to continue the state of crisis through the offer simply of more time. Roitman states: 'Without a non-foundational foundation for political action, we can only have crisis and anti-crisis, not crisis and something else' (92). 'Something else' cannot emerge from the judgement or critique that is embedded in crisis. That is not to say that we should remain blind to things having gone wrong. It is not for instance, that the NHS is not in crisis, that social care in England has not collapsed, that the financial crash of 2008 was not a global catastrophe for millions of people world-wide, nor that we do not feel ourselves to be in personal crisis when, for whatever reason, we can no longer hold all of our mental contents together. It is just that 'crisis' must operate as a non-place in the formulation of that question (what has gone wrong) in order that 'something else' may emerge. 


\section{General Practice}

'A', Will writes, 'is someone who comes to mind. Aged 42, diagnostic descriptors are hard to pin down. He comes to the practice with an array of symptoms and difficulties, his mind full of what can appear to be random sequences of events that trouble him. He can be impetuous, he seems to want us to see him as dysfunctional, someone who is unable to cope. Questions of the 'truth' slip around, even as the reality of his need is clear, leaving us in a constant dilemma:

"I can't walk a single step, I can't move. I need a visit'.

'It would be better if you could come in and see us'.

'I can't stand up'.

Although there are no appointments, 'I'll book you in to come and see us later today'.

Four hours later he will arrive to be seen. It may be that the sensation of not being able to walk won't be mentioned again. Alongside a pervasive anguish, various ongoing symptoms; I offer pragmatic treatment options for each, a kind of path of least resistance. He is someone for whom the boundaries that govern and hold together a permanently overstretched service are more elastic. If he's an hour, two hours late, I will still see him. On paper, this is hard to defend. One day we may be caught out in some audit trail or other. Yet in a very fragmented way it seems to work. He remembers me well enough. He seems to feel the visit has been helpful, even if neither of us can quite put our finger on why. We both know it will go on like this, seeing each other in this way, for a while longer at least.

Will works as a General Practitioner (GP) in an inner city practice in a large city in England. It is located in a dense urban borough, with high indicators of both inequality and poverty, including child poverty, high unemployment and pay inequality rates, and high infant mortality. General practice in the English healthcare system has a particular relation to locality, community and notions of 'home-based care'. GPs are often the first point of contact for anyone with a physical or mental health problem, their role being to treat 'common' illnesses close to home and decide when to refer on to hospitals and other services for urgent and specialist treatment. As Will describes it, primary care, as the first and often only point of entry into the wider health service, is always open. This puts enormous pressure on staff in GP surgeries and contributes to the continual anxieties as to what general practice is, and what it is for (Baird et al., 2016). Whilst one discourse frames GPs as looking after the 'whole' person, in which all aspects of human experiences - physical, emotional, social, cultural, political, economic - 'are legitimate concerns of the general practitioner, provided they are presented as a problem by the patient' (Health, 1995: 26), GPs are simultaneously caught in the currents of managerial forces which, since 1990, have forced GPs to commission services, to foster competition amongst practices, and to contribute to the marketization of the health services they can then procure. In addition, GPs are intensively targeted by the State as key to population health management through health promotion and prevention and the continual collection of population health data (Buetow \& Docherty, 1995; McDonald et al., 2007). Whilst at an individual level GPs may see their practice as a precarious balance of diagnosis, risk management, containment, treatment, and watchful waiting, they are simultaneously instrumental in taking forward government policy on 'population health. 8

GPs are not simply 'gate-keepers' to specialist services, however, but to the time embedded in care. If we follow Dana Luciano's notion of 'chronobiopolitics' (Luciano 2007: 9), we can claim that the institutional arrangement of time in the general practitioner's surgery is the arrangement of the time of 'life' itself (Luciano, 2007). This renders some lives visible, precious and worthy of care, and others not, through the organization and recognition of dominant temporal rhythms that produce and regulate 'life'. The pushing back of some aspects of previously centralised health care into the community has made primary care a particularly tense site for chronobiopolitical 
'binding' of flesh to bodies and bodies to the social (Freeman, 2011). Care is organized into temporal units: 'care pathways' for instance, 'clinical pathways', or statutory timelines of care such as the 18-week referral to treatment pledge. ${ }^{9}$ Furthermore, as Elizabeth Freeman elaborates, the eliciting of such care is reliant on the capacity of subjects to narrate their lives in particular ways. The modern period institutionalises 'techniques of biography such as the psychoanalytic case study, the parole hearing, and the petition for asylum, wherein access to protection or care is granted to subjects who can narrate and document the trajectory of their lives in particular ways' (Freeman, 2016: 130).

It is not just patients who narrate their lives in order access care, however. Healthcare workers are also chronobiopolitically governed, produced and regulated, in part through their own practices of narration, including their attempts to contain and think about the experiences of those they care for. Psychoanalysts Michael and Enid Balint were the first to pay close attention to the need for doctors working in general practice to narrate their experiences, forming 'Balint groups' to provide a space to think about the emotional impact of relations with particular patients, especially where the encounter may have left doctors feeling inexplicably stuck, depleted, or confused (Balint \& Balint, 1961). In a Balint group, a doctor will give a brief case description of an encounter with a patient. Through a process of kindling curiosity in themselves and others about what is going on for this patient, there is the chance that they may be able to elicit some respite, understanding, and to some degree, some care from their colleagues that may otherwise be shut down by defences against becoming overwhelmed by emotional disturbance and despair.

In the remainder of this chapter we illustrate Will's experience of offering waiting as a form of care in situations in which patients, for multiple and complex reasons, may feel and find themselves to be in chronic crisis. It does not describe all of Will's work, by any means. But it describes an element of his work that has to do with the offer of waiting. We have bound together some of his experiences into a series of short co-written vignettes that hover between fiction, anecdote, and case note. They do not represent any one individual patient and are therefore not offered as some form of qualitative 'data' out of which our reflections are built. Instead we have worked the other way around. Taking a fragment of experience and narrativising it, and then trying to understand it in a more collective way, is a form of theorizing that Lisa has been working with in recent years (Baraitser, 2009a, 2009b, 2012). Taking her lead from Jane Gallop's 2002 text, Anecdotal Theory, the personal, incidental or occasional is used to generate new understandings of the multiple paradoxes of writing, subjectivity, knowledge and power. Gallop leans on anecdote as a literary form that specifically challenges the social and political processes of legitimation that divide experience into the proper and the improper, the theoretical and the 'merely' anecdotal (Loveless, 2011). Anecdotal writing deliberately encourages the 'personal' as a kind of uncomfortable intrusion that disrupts theory, causing it to rethink itself: '[...] it is precisely this ability to interrupt and divert a project conceived in theory which makes incident a force with which theory must reckon' (Gallop, 2002: 15), where it is forced, that is, to think. The 'incident' that Gallop refers to is both the event that an anecdote is set up to relate (anecdotes relate singular stories, those that cannot be generalized), and the fact of its incidental nature - that it remains slight, marginal, a set of associations, nothing in particular, 'merely anecdotal'. It relies, in fact, on the singularity of the personal witness, the fact of its unverifiability for it to remain anecdote and precisely not fact or truth (Loveless, 2011:24). Each of the vignettes presented here started in this way - something that struck Will in the surgery about his own reaction to working with patients who present in chronic crisis. We have used this occasion to think through chronicity, crisis, and vulnerability, and how care may continue to operate as a response and function of all three.

9 The NHS Constitution gives patients in England the legal right to access services within maximum waiting times. This is currently 18 weeks for referral to treatment. See the Handbook to the NHS Constitution. 


\section{Enduring Crisis}

$M$ has had a very unlucky last 10 years in physical health: he sees myriad specialists, all his symptoms pressing, making life hard: brain, throat, bladder, bowel, legs, all in pain. Each will push to the front for a time, to be superseded by another. His arrival in the consulting room is signalled in advance by the colostomy that has always resisted easy day to day maintenance. He is someone effectively tortured by their body and its infirmity, who retains a sliver of hope in yet more specialists and more medications. I offer a holistic approach: to try the hospice, NOT as end of life care, but as an option to look at the situation through symptoms rather than diagnoses. It is rejected; cannot be contemplated. His multiple specialists engage in a collusion of anonymity. The space of the consultation is an index case of the container that cannot contain or process the tasks at hand. I am often left in a numb state of therapeutic nihilism. All I can offer is to see him again.

In general practice, crisis is a shifting and elusive term. Along with 'breakdown' it is not routinely used to describe medical situations. When a patient becomes very ill, some notion of a medical crisis might become recognizable, but the GP's role is to refer on to emergency medicine or to a specialist, so that they rarely get involved in crisis management in this more formal sense. It is the specialist who revels in crisis. Will describes how very occasionally something that could get called a 'medical crisis' may emerge in the surgery. In what appears to be a routine consultation, some part of the history 'sticks out' in a way that has a sudden and obvious gravity. It may be a symptom or a physical sign, a description of a sensation, or indeed something about a mental state that is striking and stirs up some form of concern. This is a moment when everything turns on its head, and what may have been a scattered state of mind - boredom, irritation, exhaustion, being at a loss - becomes a clearer and more embodied experience. It is as though epistemologically the air thins, the tension goes out of the situation, and the room becomes a place of exchange, alertness and meaning. Something can be communicated between patient and doctor that seems to bypass thinking, and in some senses calls for no judgement as such; it is in the realm of the visceral, and hard to describe. The power of this momentary process is both striking, and consoling, a form of relief. We might even talk about 'the consolations of crisis'.

But mostly, when crisis is used in general practice, it has to do with a form of elongated vigilance and care for patients with medically unexplained symptoms, or chronically difficult states of mind who, for multiple and often complex interlocking reasons, have seen a return of what troubles them, or at least have discerned that they have reached a new pitch of difficulty. The 'Crisis Team' (as a description of short term rapid access to mental health provision) was a longstanding trope in general practice over the last two decades but has largely now been suspended, replaced by the 'Crisis Resolution and Home Treatment Team', which will step in during an escalation of mental health difficulties. The shift from crisis to crisis resolution is telling. Crisis is precisely what cannot be endured and must be brought to some form of resolution. Crisis, anti-crisis. And then more crisis.

Yet one example of the resurfacing of the term 'crisis' in primary care stays with Will - his experience during his training of watching another GP, many years ago, in an out of hours setting, listening to a long account from a relative about her brother's breakdown. After hearing the story Will recalls the GP saying simply: 'This sounds a very considerable crisis, maybe the worst crisis you've ever had as a family'. Crisis is recruited as a lay word, not as judgement but as a way to signal and affirm that something very terrible has had to be faced, and will go on being faced. Crisis is named, not as prognosis out of which the breakdown will be repaired in some notional future, but as an elongated and ongoing event that can nevertheless be known, and go on being known about, by someone else: your brother's breakdown has had a terrible effect on you and your family. This is all we can know. It means a hiatus in the capacity for the future to repair the present.

J is aged 29. Formerly a heavy cannabis user she is someone I used to know well. She switched to a colleague for some years, and is now back with me. I think of her as a rolling stone; she spends long periods homeless, and is currently sofa surfing, she is quick to anger, very often arrangements break down, housing placements especially. We've bent the rules - we've encouraged her to stay on our books despite a latest housing placement miles away. If we 
just invoke the rules she has to switch GP. How does that help to contain the waves of crisis? In turn these are driven by external events:

'I need a letter'. Time and time again.

'I lost my medication'.

'I'm about to be made homeless'.

She contains her distress - just - she is amazingly resilient, in a life that would defeat me after 3 days. But if I invite some inquiry that opens up an exchange between us about what's happening, and what might have led to what is happening, I've had the response 'I don't want your bedtime stories'.

There appears to be some attempt by patient and doctor to go on being in contact, even as the dependency is hated, as the overt offer of care is experienced as intrusive, patronizing, inappropriate. 'Bending the rules' to stay on the books neither responds, nor does not respond to the current crisis, but could be understood as a commitment to going on without decision or judgement about the right course of action. The 'going on' gestures towards a temporality of endurance, of waiting without knowing what exactly either party are waiting for, closer perhaps to a 'waiting with', uncoupled from a 'waiting for' that may characterize waiting in 'modern times' (Salisbury, 2012). Somehow, even over many years, and with so little possibility for the things that Lauren Berlant would describe as the fraying elements of the post-war fantasy of a good life (upward mobility, job security, political and social equality, and lively, durable intimacy) a connection is maintained (Berlant, 2011: 3). J stays on the books. This is the form that care takes in conditions that Berlant would call 'crisis ordinariness', the social conditions that force people to adapt to unfolding and perpetual change (10).

Perhaps the term 'watchful waiting' does not really capture the form that care can take here, and 'relationship' may be only relevant in the loosest sense. Anything on offer from a medical practitioner might be quite indeterminate - in ideal terms, perhaps a capacity to stay thoughtful and attuned. Melanie Klein talks about regression that accompanies illness, bringing with it early defensive processes such as splitting, and paranoidschizoid states of mind that help to ward off the terrors of physical and psychic disintegration. Perhaps the only thing the GP has to offer is the communication: 'I'd like to see you again'. It may be offered out of desperation, out of depletion, having run out of ideas, as a defence against exasperation - in Kleinian terms, even out of hatred. Yet 'I'd like to see you again, tomorrow, in a week's time, in three weeks... opens up a form that time can take, at a time when time cannot take form. It is a form of care that makes time in the 'crisis ordinariness' precisely by refusing to engage in anti-crisis.

Sometimes a tacit or explicit settlement is made whereby the rules can be bent an 'agreed' amount. A classic flash point - a patient orders their benzodiazepine regular script 5 days early. It's likely they're overusing. Do we issue or not? What constitutes care in this moment? Dr Z doesn't know these tacit rules and says 'no!', we won't issue the script. Then a shouting match ensues in the reception area. Anxiety and desperation translates into hostility, and 'difficult to manage behaviours' spill out everywhere, tension gets spread and projected around the organisation and beyond. Cruelty is often not far below the surface as it is passed back and forth between depleted patients, and depleted healthcare workers, their energy and patience drawn thin.

Yet even this crisis has its own chronicity. There are timelines of illness, of addiction, even of some 'disorders' of the personality that have a life span, one that unfolds as an eventual burning out over time. The teaching on addiction suggests that for some, the craving eventually, over time, simply subsides. The task of care then becomes those pragmatic measures needed to keep a person alive for the 20 years or so that it may take for that subsidence. Maintaining a position of hovering and adjusting over decades entails a series of concrete prosaic interventions: keeping vaccinations up to date, timely housing letters to prevent eviction, trying to enable adequate diet, parenting support. Care in this context is simply the tacit agreement to remain present, in touch, and to go on taking these vital, ordinary steps. The hope is that enough of a life remains intact at the 'end' for something to be reclaimed. 
Crisis cannot always be contained within the consulting room - it has a tendency to 'spill' because it is affectively charged, full of anxiety, uncertainty, anger and despair. As distress becomes public, the relation between individual and systemic crisis is less easy to keep apart. Everyone is depleted by the daily struggle to manage their sense of overwhelm, their 'chronic state of near-collapse'.

It is a moment in which one could at least imagine a collective diagnosis of crisis, one that might then give rise to some form of collective action, a coming together of all those who suffer from the current crisis in the NHS healthcare workers and patients alike. A.T. Kingsmith (2018) calls for this potential for collective action through the recognition of 'affectarity'. 'Affectarity', like 'precarity' describes 'insecure access to the means to survive or flourish' (Holmes, 2003, quoted in Kingsmith, 2018). But it also attempts to capture the affective regimes of different historical eras and the potential of the 'reactive affects' they produce. Activism, that is, has always operated through reactive forms of affect - reacting to misery drove activism in the $19^{\text {th }}$ century, and reacting to boredom drove resistance to dominant forms of power in the Fordist years. In the contemporary period of globalized capitalism, Kingsmith calls for activism that collectively mobilises anxiety, redirecting our energies towards 'interrupting' its construction:

While traditional tactics can and still work effectively against more traditional forms of violence and repression, an affective activism can help to directly confront our anxieties by conveying that it is 'good' and 'positive' to express our viscerality, to be collectively angry and to convey anger every time we confront the affect management of capitalism'. (69)

In an age of anxiety, we need to replace fear with anger, individual anxiety with collectivity, and sadness with anticipation. Kingsmith suggests that:

Beginning by seeing personal problems and small injustices as symptoms of wider structural problems has the power to initiate the 'frightening' (active) as opposed to the 'frightened' (reactive) characteristics of a politically salient affectariat. (Kingsmith 2018,76)

How does this sit, however, with Roitman's notion of anti-crisis? Surely this turn to affective anti-crisis can only lead to more crisis and not something else? Indeed, we have been suggesting here that this 'something else' emerges through an acknowledgement of what Melanie Klein would call 'depressive anxiety' - a capacity to go on knowing about crisis without attempts at manic repair, through fostering forms of connection that consist of waiting with, enduring with, staying with, staying alongside, and through the continual offer of simply seeing someone again. Returning to Puig de la Bellacasa, in her discussion of 'soil time' (Puig de la Bellacasa, 2017) she elaborates permaculture practices of 'thoughtful and protracted observation' (201) before acting on the land as constituting 'care time' (171) through a form of slow, repeated, ongoing watching and waiting. Understanding soil time involves a form of 'passivity', she claims, a withdrawal of the self, but also of identified outcomes in relation to 'caring about' and 'caring for' (198). We would think about this withdrawal under the term 'depression', a necessary withdrawal that can respond to the very logic of crisis that refuses to be overturned by strategies of anti-crisis. Indeed, depression may turn out to be a more salient affect than permanent anxiety for understanding the affective regime of late capitalism, both in its debilitating but also in its reparative modes. What Donna Haraway calls 'staying with the trouble' (Haraway, 2016) may entail the suspension of judgement, and a form of watchful waiting that constitutes a capacity to endure crisis rather than seek to mobilise against it.

\section{Acknowledgements}

This paper was developed in collaboration with colleagues working on the research project, Waiting Times, supported by The Wellcome Trust [205400/A/16/Z], (see waitingtimes.exeter.ac.uk). We are grateful to Kelechi Anucha, Jocelyn Catty, Stephanie Davies, Michael J. Flexer, Martin Moore, Martin O’Brien, Deborah Robinson, 
Raluca Soreanu, and especially Laura Salisbury, who have influenced the direction of our thinking, and provided invaluable insights about waiting, care and vulnerability. Our thanks are also to Victoria Browne, Jason Danely, and Doerthe Rosenow for expert editorial input.

\section{References}

Appleby, J. (2013) Spending on health and social care over the next 50 years: why think long term? London: The King's Fund. Available at: www.kingsfund.org.uk/time-to-think-differently/publications/spending-healthand-social-care-over-next-50-years. Accessed 01.04.2019.

Baird, B., Charles, A., Honeyman, M., Maguire, D., Das, P. (2016) Understanding pressures in general practice. London: The King's Fund. Available at: www.kingsfund.org.uk/publications/pressures-in-general-practice. Accessed 01.04.2019.

Balint, M. (1986) The doctor, his patient and the illness. London. Pitman Medical, 2nd edition (1964).

Balint, M., \& Balint, E. (1961) Psychotherapeutic Techniques in Medicine. London: Tavistock publications.

Baird, B., Charles, A., Honeyman, M., Maguire, D., Das, P. (2016) Understanding pressures in general practice. London: The King's Fund. Available at: www.kingsfund.org.uk/publications/pressures-in-general-practice. Accessed 01.04.2019.

Balint, M. (1986) The doctor, his patient and the illness. London. Pitman Medical, 2nd edition (1964).

Balint, M., \& Balint, E. (1961) Psychotherapeutic Techniques in Medicine. London: Tavistock publications.

Baraitser, L. (2009) Maternal Encounters: The Ethics of Interruption. London and New York: Routledge.

Baraitser, L. (2012) 'Maternal Publics: Time, Relationality and the Public Sphere', in Critical Explorations through Psychoanalysis: In-between dynamics of psychic singularity and praxis of universal solidarity. Ed. A. Gulerce. Basingstoke: Palgrave.

Baraitser, L. (2009) 'Redundant groupings and the ethico-political subject: Mothers who make things public'. Special Issue: Birth. Feminist Review: 93: 8-23.

Baraitser, L. (2017) Enduring Time London: Bloomsbury.

Benjamin, W. (1999) The Arcades Project. Translated by Howard Eiland and Kevin McLaughlin. Cambridge MA: Belknap Press.

Berlant, L. (2011) Cruel Optimism Durham: Duke University Press.

Bevan, G., \& Hood, G. (2006) 'Have Targets Improved Performance in the English NHS?' BMJ, 332: 419-22. PubMed PMID: 16484272.

Bottery, S., Varrow, M., Thorlby, R., Wellings, D. (2018) A fork in the road: Next steps for social care funding reform. King's Fund, Health Foundation. Available at: https://www.kingsfund.org.uk/sites/default/files/ 2018-05/A-fork-in-the-road-next-steps-for-social-care-funding-reform-May-2018.pdf. Accessed 01.04.2019.

Bridgen, P. (2001) 'Hospitals, Geriatric Medicine, and Long-Term Care of Elderly People, 1946- 1976', Social History of Medicine, 14: 507-23 PubMed PMID: 11811191.

Buetow, S., Docherty, B. (1995) 'The seduction of general practice and illegitimate birth of an expanded role in population health care'. Journal of Evaluation in Clinical Practice, 11: 397-404.

Cazdyn, E. (2013) The Already Dead: The New Time of Politics, Culture, and Illness. Durham: Duke University Press.

Chakrabarty, D. (2009) 'The Climate of History: Four Theses'. Critical Inquiry, 35: 197-222.

Charles-Jones, H., Latimer, J., May, C., (2003). 'Transforming general practice: the redistribution of medical work in primary care'. Sociology of Health \& Illness, 25: 71-92. PubMed PMID: 14498945. 
Charlesworth A, Thorlby R, Gershlick B, (2017). Election briefing: NHS and social care funding - three unavoidable challenges. The Health Foundation. Available at: www.health.org.uk/publication/electionbriefing-nhs-and-social-care-funding (accessed on 12 June 2018).

Crary, J. (2013) 24/7: Late Capitalism and the End of Sleep. London: Verso.

Denham, M. (2006) 'The Surveys of the Birmingham Chronic Sick Hospitals, 1948-1960s', Social History of Medicine, 19: 279-93.

Duffy, E. (2009) The Speed Handbook: Velocity, Pleasure, Modernism. Durham: Duke University Press.

Elias, A. (2016) 'Past/Future', in Joel Burges and Amy Elias, eds. Time: A Vocabulary of the Present New York: New York University Press.

Emmerson, C., Pope, J. (2018) The NHS's “70th birthday present” and the public finances. Institute for Fiscal Studies, 2018. Available at: https://www.ifs.org.uk/publications/13078. Accessed 01.04.2019.

Fraser, N. (2016) 'Contradictions of Capital and Care'. New Left Review, 100, available at https:// newleftreview.org/issues/II100. Accessed 01.04.2019.

Freeman, E. (2010) Time Binds: Queer Temporalities, Queer Histories. Durham and London: Duke University Press.

Gallop, J. (2002) Anecdotal Theory. Durham and London: Duke University Press.

Gorsky, M. (2013) "'Searching for the People in Charge": Appraising the 1983 Griffiths NHS Management Inquiry', Medical History, 57: 87-107 PubMed PMID: 23393404.

Ham, C. ( 2019.) Available at: https://www.kingsfund.org.uk/publications/funding-boost-nhs-england

Ham C, Edwards N, Dixon J. (2018) 'An open letter: a long-term funding settlement for the NHS'. King’s Fund, Nuffield Trust, Health Foundation, 2018.

Haraway, D. (2016) Staying With the Trouble: Making kin in the chthulucene. Durham: Duke University Press. Available at: https://www.kingsfund.org.uk/publications/pm-letter-funding-settlement-nhs. Accessed 01.04.2019.

Heath, I., (1995) 'The mystery of general practice', available at: https://www.nufieldtrust.org.uk/research/themystery-of-general-practice.1.11.1995. Accessed 01.04.2019.

Invisible Committee, The. 2009. The Coming Insurrection. New York: Semiotext(e).

Invisible Committee, The. 2014. To Our Friends, New York: Semiotext(e).

Kingsmith, A.t. (2018) We The Affectariat: Activism and boredom in anxious capitalism. Rhizomes Available at: https://doi.org/10.20415/rhiz/034.e07. Available at: http://www.rhizomes.net/issue34/kingsmith/index.html. Accessed 01.04.2019.

Klein, M. (1940) 'Mourning and its relation to manic depressive states' Int. J. Psycho-anal, 21: 125-153.

Klein, R. (2006) The New Politics of the NHS: From Creation to Reinvention, 5th Edition. Oxford: Radcliffe.

Koselleck, R. (2002) The Practice of Conceptual History: Timing History, Spacing Concepts. Stanford, CA: Stanford University Press.

Koselleck, R. (1988) Critique and Crisis: Enlightenment and the pathogenesis of modern society. Cambridge, MA: Berg, 1959.

Koselleck, R. (2004) Futures Past: On the Semantics of Historical Time. New York: Columbia University Press, 1979.

Koselleck, R. (2006). 'Crisis', Journal of the History of Ideas, 67: 357-400.

Loveless, N. (2011) 'Reading with Knots: On Jane Gallop's Anecdotal Theory'. Journal of the Jan van Eyck Circle for Lacanian Ideology Critique 4: 24-36. 
Luhmann, N. (1976) 'The Future Cannot Begin: Temporal structures in modern society'. Social Research, 43: $130-152$.

Luciano, D. (2007) Arranging Grief: Sacred Time and the Body in Nineteenth-Century America New York: New York University Press.

McDonald, R., Harrison, S., Checkland, K., Campbell, S.M., Roland, M., (2007) 'Impact of financial incentives on clinical autonomy and internal motivation in primary care: and Ethnographic Study'. British Medical Journal 334: 1357. PubMed PMID: 17580318.

Meek, J. (2018) 'NHS SOS'. London Review of Books, Vol 40 (7) 17-30. 5th April 2018

National Audit Office. (2016) Financial sustainability of the NHS. Norwich: TSO (The Stationery Office). Available at: www.nao.org.uk/wp-content/uploads/2016/11/Financial-Sustainability-of-the-NHS.pdf. Accessed 01.04.2019.

NHS England. (2014) NHS five year forward view [online]. London: NHS England. Available at: www.england.nhs.uk/ourwork/futurenhs. Accessed 01.04.2019.

NHS England. (2015) Guidance to Support the Introduction of Access and Waiting Time Standards for Mental Health Services in 2015/16. Available at: https://www.england.nhs.uk/wp-content/uploads/2015/02/mhaccess-wait-time-guid.pdf. Accessed 01.04.2019.

Nanni, G., (2012) The Colonisation of Time: Ritual, routine and resistance in the British Empire. Manchester \& New York: Manchester University Press.

Nixon, R. (2011) Slow Violence and the Environmentalism of the Poor. Cambridge, MA, Harvard University Press.

Nowotny, H. (1994) Time: The Modern and Postmodern Experience. Cambridge: Polity Press.

O'Hara, G. (2007) From Dreams to Disillusionment: Economic and Social Planning in the 1960s, Basingstoke: Palgrave Macmillan.

Perry, M. (2000) 'Academic General Practice in Manchester under the Early National Health Service: A Failed Experiment in Social Medicine', Social History of Medicine, 13: 111-130. PubMed PMID: 11624420.

Propper, C., Sutton, M., Whitnall, C., Windmeijer, F., (2008) 'Did “Targets and Terror" Reduce Waiting Times in England for Hospital Care?' The B. E. Journal of Economic Analysis and Policy, 8 (2): 5.

Puig de la Bellacasa, M., (2017) Matters of Care: Speculative ethics in more than human worlds. Minneapolis and London: University of Minnesota Press.

Rivett, G. (1998) From Cradle to Grave: Fifty Years of the NHS. London: King's Fund.

Roberts, A., Marshall, L., Charlesworth, A. (2012) A decade of austerity? The funding pressures facing the NHS 2010/11 to 2021/22. London: Nuffield Trust. Available at: www.nuffieldtrust.org.uk/publications/decadeausterity-funding-pressures-facing-nhs. Accessed 01.04.2019.

Roitman, J. (2014) Anti-crisis. Durham, Duke University Press.

Roitman, J. (2016) 'The Stakes of Crisis', in Critical Theories of Crisis in Europe: From Weimar to the Euro. Eds., Poul F., Kjaer and Niklas Olsen. London \& New York: Rowman \& Littlefield

Rosa, H. (2003) 'Social Acceleration: Ethical and Political Consequences of a Desynchronized High-Speed Society'. Constellations, 10, no 1, 3-33.

Rosa, H. (2013) Social Acceleration: A New Theory of Modernity. New York: Columbia University Press.

Rosa, H., \& Scheuerman, W. E. (eds). (2009) High-Speed Society: Social Acceleration, Power and Modernity. Pennsylvania: Penn State University Press.

Salisbury, L. (2012) Samuel Beckett: Laughing Matters, Comic Timing. Edinburgh: Edinburgh University Press.

Southwood, I. (2011) Non-stop Inertia. Hants: Zero Books. 
Szerszynski, B. (2017) ‘The Anthropocene monument: On relating geological and human time', European Journal of Social Theory, 20(1): 111-131.

Thorlby R, Starling A, Broadbent C, Watt T (2018) What's the problem with social care, and why do we need to do better? London: Health Foundation.

Timmins, N. (1996) The Five Giants: A Biography of the Welfare State. London: Fontana Press.

Vázquez, R. (2009) 'Modernity, Colonality and Visibility: The Politics of Time', Sociological Research Online, 14, No 4. < Available at: http://www.socresonline.org.uk/14/4/7.html> doi:10.5153/sro.1990

Virilio, P. (1986) Speed and Politics: An Essay on Dromology. New York: Semiotext(e), 1977.

Virilio, P. (2010) The Futurism of the Instant: Stop-Eject. Cambridge: Polity Press.

Wajcman, J. (2014) Pressed for Time: The Acceleration of Life in Digital Capitalism. Chicago: Chicago University Press.

Williams, F. (2010) 'Migration and Care: Themes, concepts and challenges'. Social Policy \& Society, 9(3): 385396.

Williamson, C. (2015) 'The Quiet Time? Pay-beds and Private Practice in the National Health Service: 19481970', Social History of Medicine, 28: 576-95. 